\title{
Defense induced by a bis-aryl methanone compound leads to resistance in potato against Phytophthora infestans
}

\author{
Mohammad Shahjahan Monjil · Daigo Takemoto • \\ Kazuhito Kawakita
}

Received: 14 May 2013/Accepted: 18 August 2013/Published online: 18 October 2013

(c) The Author(s) 2013. This article is published with open access at Springerlink.com

\begin{abstract}
Plants recognize certain microbial compounds as elicitors of their active defense mechanisms. In the present study, NUBS-4190, a synthetic bis-aryl-methanone compound elicited NO and ROS generation in potato suspension cultured cells and intact potato leaves. Hypersensitive cell death was found in these cultured cells and in potato leaves without the accumulation of phytoalexins in the tubers. Defense-related genes such as StrbohB, StrbohC, StNR1, StNR5, Sthsr203J and StPRI were expressed in potato suspension cultured cells treated with NUBS-4190. Resistance against Phytophthora infestans also increased in NUBS-4190-treated potato leaves.
\end{abstract}

Keywords Bis-aryl methanone - Nitric oxide ·

Phytophthora infestans - Potato - Reactive oxygen

species - Resistance

\section{Introduction}

Early recognition of a pathogen by a plant is essential for the plant to activate the available biochemical and structural defenses against the pathogen. Once a particular plant molecule recognizes and reacts with bioactive compound(s), alarm signals are transduced to host cell molecules and to nuclear genes to activate the production of protective substances against the pathogen. Early responses involving ion influx, production of nitric oxide (NO) and reactive oxygen

M. S. Monjil

Department of Plant Pathology, BAU, Mymensingh 2202,

Bangladesh

D. Takemoto $\cdot$ K. Kawakita $(\bowtie)$

Graduate School of Bioagricultural Sciences, Nagoya

University, Chikusa, Nagoya 464-8601, Japan

e-mail: kkawakit@agr.nagoya-u.ac.jp species (ROS), such as $\mathrm{H}_{2} \mathrm{O}_{2}$ and $\mathrm{O}_{2}{ }^{-}$, then transduce the elicitor signal to downstream defense responses as signalling molecules (Zhao et al. 2005). These early events are followed by other defense responses including induction of HRlike cell death, limiting pathogen spread (Apel and Hirt 2004), and further reinforcement of the cell walls and increased expression of defense-associated genes (Mur et al. 2008).

In plants, NO is known to participate in several responses, including germination, flowering, stomatal closure and pathogen defense (Besson-Bard et al. 2008; Delledonne et al. 1998; Durner et al. 1998; Wilson et al. 2008). NO participates in the complex interplay of defense-related signalling pathways controlling disease resistance (Perchepied et al. 2010). NO and target genes of NO contribute to the oligogalacturonide-triggered responses against Botrytis cinerea (Rasul et al. 2012), NO participates as a partner of ROS in disease resistance to $B$. cinerea in Nicotiana benthamiana (Asai and Yoshioka 2009). This involvement of NO in plant disease resistance is related to its interplay with ROS, and cell death during hypersensitive response (HR) may result from the simultaneous and balanced production of $\mathrm{NO}$ and ROS (Zaninotto et al. 2006). NO and ROS exert reciprocal control on each other (Arasimowicz-Jelonek et al. 2009; Cecconi et al. 2009; Clarke et al. 2000). In the context of plant-pathogen interactions, NO is involved in the modulation of salicylic acid, jasmonic acid, and ethylene synthesis and possibly other response mechanisms in plants (Delledonne 2005; Huang et al. 2002; Parani et al. 2004).

Another feature of disease resistance in many plants is the rapid collapse and death of challenged cells in the $\mathrm{HR}$, a form of programmed cell death (PCD) in plants (Dangl et al. 1996; Lam et al. 2001). Hypersensitive cell death depends on $\mathrm{O}_{2}{ }^{-}$ and $\mathrm{H}_{2} \mathrm{O}_{2}$ generation, is a key player accompanying the defense (Heath 2000; Torres 2010; Zurbriggen et al. 2009). 
$\mathrm{H}_{2} \mathrm{O}_{2}$ involvement is also reported in many types of PCD induced by abiotic stress. Indeed, $\mathrm{H}_{2} \mathrm{O}_{2}$ is involved in the PCD induced by heat shock in tobacco BY-2 cells (Locato et al. 2008; Vacca et al. 2004) and in the hypoxia-induced lysigenous aerenchyma formation in Arabidopsis (Mühlenbock et al. 2007). Treatment with NO generators contradictorily results in diminishing ROS effects (Noritake et al. 1996; Orozco-Cárdenas and Ryan 2002) or in increasing them (Delledonne et al. 2001; Murgia et al. 2004). The balance between ROS and NO has also been proposed to be a critical aspect in inducing PCD (Delledonne et al. 1998, 2001).

Many elicitors have been isolated from various organisms, including bacteria, viruses, oomycetes and fungi. Typical examples of general elicitors are chitin (Felix et al. 1993), bacterial flagellin (Felix et al. 1999; Zipfel et al. 2004), elicitins from Phytophthora species such as cryptogein in their apoplast (Billard et al. 1988) or oomycete Pep13 (Nürnberger et al. 1994). Chemical or synthetic compounds also can have elicitor activities in plants. Cheong et al. (1991) showed that chemically synthesized oligo-8glucosides, ranging in size from hexamer to decamer, induced phytoalexin accumulation in soybean. Benzothiadiazole (BTH) and 2,6-dichloroisonicotinic acid (INA) induced resistance in different plant species as a preventive measure against pathogen growth (Goellner and Conrath 2008; Perazzolli et al. 2008; Vallad and Goodman 2004). A synthetic harmless chemical, $\beta$-aminobutyric acid induced resistance against numerous plant diseases in various pathosystems (Jakab et al. 2001).

These facts clearly show that a great diversity of elicitors, inducing various biological effects, are present in plants and crops. In the present study, we used NUBS-4190, a bis-aryl methanone (3,5-difluorophenyl-[3-methyl-4-(methylsulfonyl)isoxazol-5-yl]-methanone) to study induced resistant reactions (Fig. 1). NUBS-4190 is a synthetic compound previously reported to elicit NO and induced resistance in the model plant $N$. benthamiana against Phytophthora infestans (Monjil et al. 2013). Authors studied the defense role against pathogen, particularly to examine the effect of NUBS-4190 to ascertain early reactions and to evaluate the induced resistant reactions in potato plants and suspension cultured<smiles>Cc1onc(C(=O)c2cc(F)cc(F)c2)c1S(C)(=O)=O</smiles>

Fig. 1 Chemical structure of NUBS-4190 or 3,5-difluorophenyl-[5methyl-4-(methylsulfonyl)isoxazol-3-yl]-methanone potato cells. This study also examines the defense strategy in potato- $P$. infestans interactions and defense activities in potato in response to the NUBS-4190.

\section{Materials and methods}

Test plants

Suspension cultured potato cells, leaves and tubers of cultivar Sayaka, which has resistant genes $R 1$ and $R 3$, were used: suspension cultured cells are very sensitive to early responses to NUBS-4190 treatment; intact potato leaves were used to observe elicitor responses in more natural conditions; tubers are the best material for examining phytoalexin production (unpublished data by M. S. Monjil and K. Kawakita). Suspension cultured cells were prepared from callus obtained from potato tuber discs in callusinducing solid medium $[1 \mathrm{~mL} / \mathrm{L}$ B5-vitamin $(100 \mathrm{~g} / \mathrm{L}$ myoinositol, $2.5 \mathrm{~g} / \mathrm{L}$ glycine, $500 \mathrm{mg} / \mathrm{L}$ thiamine- $\mathrm{HCl}$, $500 \mathrm{mg} / \mathrm{L}$ pyridoxine- $\mathrm{HCl}, 5 \mathrm{~g} / \mathrm{L}$ nicotinic acid, $50 \mathrm{mg} / \mathrm{L}$ biotin, $50 \mathrm{mg} / \mathrm{L}$ folic acid), $2 \mathrm{mg} / \mathrm{L}$ naphthalene acetic acid (NAA), $0.5 \mathrm{mg} / \mathrm{L}$ kinetin, $3 \% \mathrm{w} / \mathrm{v}$ sucrose, $0.2 \% \mathrm{w} / \mathrm{v}$ Phytagel and Murashige-Skoog basal medium], in the dark. Suspension cultured cells were shake-cultured at $100 \mathrm{rpm}$ at $23{ }^{\circ} \mathrm{C}$ in $80 \mathrm{~mL}$ of MS broth supplemented with $1 \mathrm{~mL} / \mathrm{L}$ vitamin complex (100 g/L myo-inositol, $2.5 \mathrm{~g} / \mathrm{L}$ glycine, $500 \mathrm{mg} / \mathrm{L}$ thiamine- $\mathrm{HCl}, \quad 500 \mathrm{mg} / \mathrm{L}$ pyridoxine- $\mathrm{HCl}$, $5 \mathrm{~g} / \mathrm{L}$ nicotinic acid, $50 \mathrm{mg} / \mathrm{L}$ biotin, $50 \mathrm{mg} / \mathrm{L}$ folic acid), $2 \mathrm{mg} / \mathrm{L}$ NAA, $0.5 \mathrm{mg} / \mathrm{L}$ kinetin, $3 \%$ sucrose and Murashige-Skoog basal medium. Cells were subcultured every week and used for experiments 4-5 days after the subculturing. Potato plants were grown at $23{ }^{\circ} \mathrm{C}$ and $70 \%$ humidity with a $16 \mathrm{~h}$ photoperiod in environmentally controlled growth cabinets, and the leaves were removed for the experiments.

\section{NUBS-4190 and other elicitors}

NUBS-4190, a synthetic compound from the chemical compound library of the Plant Pathology Laboratory, Graduate School of Bioagricultural Sciences, Nagoya University, Japan was tested as an elicitor, and two other elicitors, INF1 (infl gene product) and MEM (methanol extract of mycelia from $P$. infestans), were used as positive controls in this study.

Elicitor INF1 was prepared according to the method of Yamamoto et al. (2004); overnight cultures of Escherichia coli cells, carrying a chimeric plasmid (pFB53) with the inf 1 gene (Kamoun et al. 1997), were diluted (1:100) in LuriaBertani broth containing $50 \mu \mathrm{g} / \mathrm{mL}$ of ampicillin and incubated at $37^{\circ} \mathrm{C}$. When the $\mathrm{OD}_{600}$ of cultures reached 0.6 , production of INF1 was induced by adding $0.4 \mathrm{mM}$ isopropyl 
$\beta$-D-thiogalactopyranoside. After incubating for $3-4 \mathrm{~h}$, the culture was centrifuged, and the resultant supernatant was dialyzed against water in SnakeSkin dialysis tubing (7 kDa molecular mass cutoff, Pierce Biotechnology, Rockford, IL, USA) overnight at $4{ }^{\circ} \mathrm{C}$. This preparation was then used as INF1 elicitor.

MEM was prepared as follows. Mycelia collected from $P$. infestans were frozen in liquid nitrogen and ground with a mortar and pestle. The ground mycelia were transferred to a Falcon tube $(50 \mathrm{~mL})$ containing $10 \mathrm{~mL}$ of methanol per $1 \mathrm{~g}$ mycelia, then homogenized using a polytron type homogenizer (HG30, Hitachi Koki, Tokyo, Japan) for $2 \mathrm{~min}$. After centrifugation at $4{ }^{\circ} \mathrm{C}, 3000 \times g$ for $30 \mathrm{~min}$, the supernatant was collected and dried with an evaporator for use.

\section{NUBS-4190 treatment}

The suspension cultured potato cells, the intact potato leaves and the potato tubers differ in their sensitivity to NUBS4190 , so they were treated with different concentrations. The suspension cultured cells are the most sensitive and were treated with $1 \mu \mathrm{g} / \mathrm{mL}$ NUBS-4190, and leaves were treated with $10 \mu \mathrm{g} / \mathrm{mL}$. For cell death experiments, a higher concentration $(50 \mu \mathrm{g} / \mathrm{mL})$ was applied so that cell death at the leaf surface could be clearly viewed. For phytoalexin studies in tubers, $50 \mu \mathrm{g} / \mathrm{mL}$ was used.

\section{Pathogenic isolate of $P$. infestans}

Pathogenic isolate ( $P$. infestans) race 1.2.3.4 was used throughout the research. Zoosporangia were collected, and zoospore production was induced by the methods of Doke (1975). Zoosporangia suspensions were prepared following the method of Monjil et al. (2013); the isolate was subcultured on rye medium for 7-10 days, then $20 \mathrm{~mL}$ of water was added to the surface of the colonies, which were then rubbed with a cotton swab to release the zoosporangia. NUBS-4190pretreated intact leaves were inoculated with a $1 \mathrm{~mL}$ sample of $P$. infestans zoospores $\left(2 \times 10^{5}\right.$ zoospores $\left./ \mathrm{mL}\right)$ and covered with lens paper to keep the suspension of zoospores on the surface of the leaves. The inoculated plants were kept at high humidity at $20^{\circ} \mathrm{C}$ for 1 day, and then moved to a growth room at $23{ }^{\circ} \mathrm{C}$.

\section{Measurement of NO production}

NO was detected using the method described by Monjil et al. (2013). Suspension cultured potato cells were collected and washed with assay buffer (5 mM MES-KOH,
pH 5.7, containing $175 \mathrm{mM}$ mannitol, $0.5 \mathrm{mM} \mathrm{CaCl}_{2}$, $0.5 \mathrm{mM} \mathrm{K}_{2} \mathrm{SO}_{4}$ ). They were resuspended in assay buffer and equilibrated for $1 \mathrm{~h}$ at $100 \mathrm{rpm}$ at $23{ }^{\circ} \mathrm{C}$. Cells were then treated with elicitors and incubated at $100 \mathrm{rpm}$ at $23{ }^{\circ} \mathrm{C}$ for $3 \mathrm{~h}$. NO was measured using the NO indicator diaminofluorescein-2 (DAF-2 DA; Daiichi Pure Chemicals, Tokyo, Japan). The cells were incubated with $10 \mu \mathrm{M}$ DAF-2 DA for $1 \mathrm{~h}$, then fluorescence from DAF-2T, the reaction product of DAF-2 with $\mathrm{NO}$, was measured with a fluorescence spectrophotometer (RF-5300PC; Shimadzu, Kyoto, Japan) at $30{ }^{\circ} \mathrm{C}$. The excitation and emission wavelengths for DAF-2T are $495 \mathrm{~nm}$ and $515 \mathrm{~nm}$ (band paths $3 \mathrm{~nm}$ and $3 \mathrm{~nm}$ ), respectively.

Potato leaves were infiltrated with $200 \mathrm{mM}$ sodium phosphate buffer at $\mathrm{pH} 7.4$ and $12.5 \mu \mathrm{M}$ DAF-2DA, using a needleless syringe and were incubated for $1 \mathrm{~h}$ in the dark at room temperature before observation. Fluorescence from DAF-2T was captured using a fluorescence stereomicroscope (MZ16FA, Leica, Heerbrugg, Switzerland) equipped with a CCD camera (Color 14 bit, AxioCam HRc, Carl Zeiss, Göttingen, Germany). The fluorescence intensity of the scanned field of the image captured by a CCD camera was quantified by determining the mean values for the green channel for the images with the histogram function of Adobe Photoshop 7.0 (Adobe, Seattle, WA, USA) (Boccara et al. 2005). A fluorescence image was obtained from 1 inoculated area per leaf, and at least 3 inoculated areas were analyzed as replicates for each treatment.

Measurement of $\mathrm{O}_{2}^{-}$production

Suspension cultured potato cells $(50 \mathrm{mg} / \mathrm{mL})$ were washed with the assay buffer (175 $\mathrm{mM}$ mannitol, $50 \mathrm{mM}$ MES-KOH, $0.5 \mathrm{mM} \mathrm{CaCl}_{2}$ and $0.5 \mathrm{mM} \mathrm{K}_{2} \mathrm{SO}_{4}, \mathrm{pH}$ 5.7) twice to remove liquid culture medium. For the detection of $\mathrm{O}_{2}{ }^{-}$produced by cultured cells, the cells were resuspended in assay buffer, equilibrated for $1 \mathrm{~h}$ at $100 \mathrm{rpm}$ at $23{ }^{\circ} \mathrm{C}$. Cells were then treated with elicitors and incubated at the same condition for $3 \mathrm{~h}$. After the treatment, the relative intensity of $\mathrm{O}_{2}{ }^{-}$generation was measured by counting photons from the chemiluminescence of $20 \mathrm{mM}$ L-012 (8-amino-5-chloro-7-phenylpyridol[3,4-d]pyridazine-1,4(2H,3H) dione sodium salt)-mediated using a chemiluminescence reader Mithras LB 940 (Berthold Technologies, Bad Wildbad, Germany).

Plant leaf $\mathrm{O}_{2}{ }^{-}$was measured as described by Kobayashi et al. (2007); potato leaves were infiltrated with $0.5 \mathrm{mM}$ $\mathrm{L}-012$ in $10 \mathrm{mM}$ MOPS-KOH (pH 7.4) via a needleless syringe. Chemiluminescence was monitored continuously using a photon image processor equipped with a sensitive $\mathrm{CCD}$ camera in the dark chamber at $20^{\circ} \mathrm{C}$ (Aquacosmos 
2.5; Hamamatsu Photonics, Shizuoka, Japan) and quantified using the U7501 program (Hamamatsu Photonics).

$\mathrm{H}_{2} \mathrm{O}_{2}$ in situ detection

Leaf discs of potato plants infiltrated with elicitors were removed with a cork borer at 3, 6, 12 and $24 \mathrm{~h}$ after infiltration. $\mathrm{H}_{2} \mathrm{O}_{2}$ was detected using the DAB staining method described by Thordal-Christensen et al. (1997).

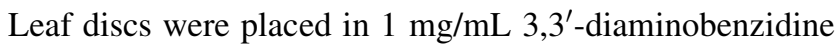
(DAB) (Sigma, St. Louis, MO, USA) and incubated at room temperature overnight. DAB reactions were examined in leaves cleared in boiling ethanol (96\%) for $10 \mathrm{~min}$. The samples were then stored in ethanol $(96 \%)$ at room temperature or mounted in phosphate-buffered saline/ glycerol $(50 \%)$ and kept at $4{ }^{\circ} \mathrm{C}$ for further examination. $\mathrm{H}_{2} \mathrm{O}_{2}$ was visualized as a reddish brown coloration.

Detection of cell death

Opposite surfaces of leaves were infiltrated with elicitors using a needleless syringe. Death areas that developed on the infiltrated leaf surface were monitored 6, 12, 24 and $48 \mathrm{~h}$ after treatment with elicitors. Cell death was also checked using an electrolyte leakage method, adapted from the method of Yeom et al. (2011). Leaves were infiltrated with elicitors under the leaf surface, and leaf discs $(1 \mathrm{~cm}$ in diameter) were collected from the leaf 3, 6 and $12 \mathrm{~h}$ after treatment. Seven leaf discs were floated on $7 \mathrm{~mL}$ of distilled water for $2 \mathrm{~h}$ at room temperature, and electrical conductivity was measured using a conductivity meter (Horiba, Kyoto, Japan).

\section{Detection of phytoalexins}

Potato phytoalexins produced in potato tubers were extracted using ethyl acetate following the method described previously (Noritake et al. 1996) with a little modification. Concave holes (diameter $15 \mathrm{~mm}$, depth $7 \mathrm{~mm}$ ) were drilled in the parenchyma of the sliced tuber about $10-15 \mathrm{~mm}$ thick with an electric drill. After aging at $20{ }^{\circ} \mathrm{C}$ for $24 \mathrm{~h}$ in dark humid chamber, $500 \mu \mathrm{L}$ of each treatment was added to the concave hole and was

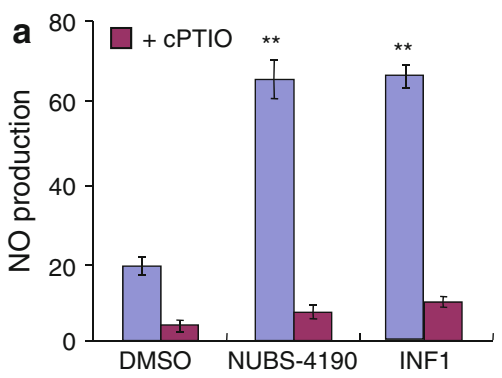

c
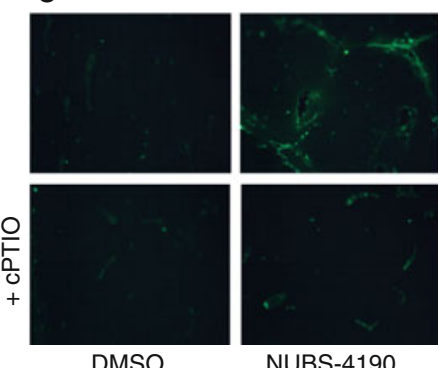

NUBS-4190

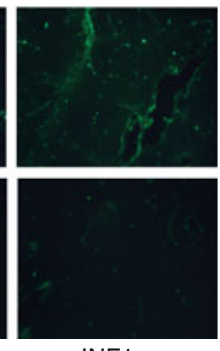

INF1

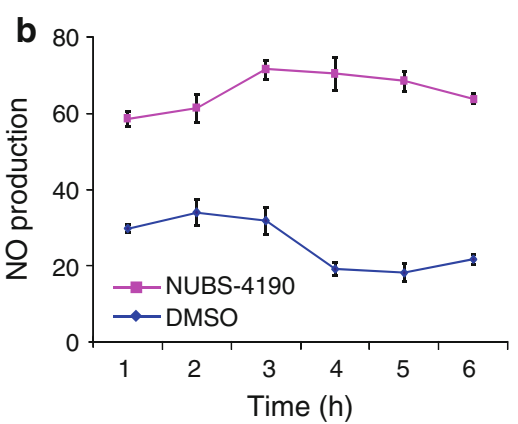

d

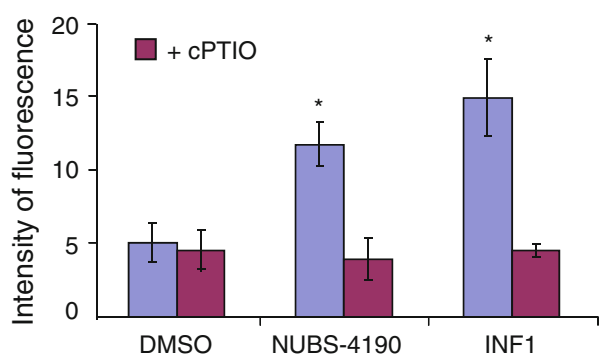

cells up to $6 \mathrm{~h}$. $\mathbf{c}$ Potato leaves were infiltrated with $10 \mu \mathrm{g} / \mathrm{mL}$ NUBS4190 and incubated for $12 \mathrm{~h}$ before NO measurement. The treated leaf areas were infiltrated with DAF-2DA solution and were monitored $1 \mathrm{~h}$ later using fluorescence stereomicroscopy. DMSO (1\% v/v) and INF1 $(150 \mathrm{nM})$ were used as negative and positive control, respectively. In a separate experiment (lower panel), treated leaf areas were infiltrated with $1 \mathrm{mM}$ cPTIO $1 \mathrm{~h}$ before infiltration with DAF-2DA. d Signal intensities were quantified by determining the mean channel values for the images with the histogram function. Each value represents the mean and standard deviation of 5 replicates. Data were subjected to Student's $t$ test. $* P<0.05$, $* * P<0.01$ and $* * * P<0.001$ vs DMSO control treatment 


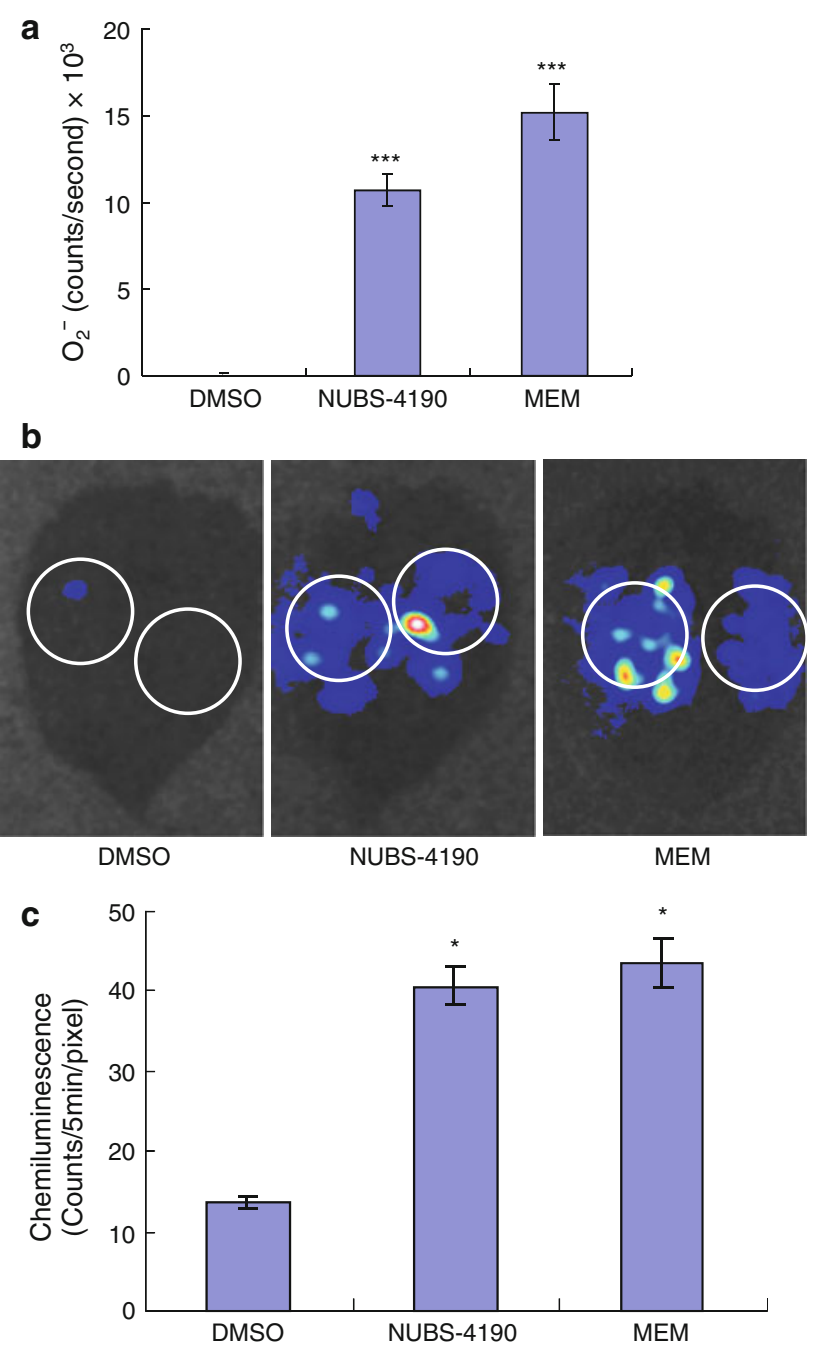

Fig. $3 \mathrm{O}_{2}^{-}$inducing activity of NUBS-4190 in potato. a NUBS-4190induced $\mathrm{O}_{2}^{-}$generation was measured in suspension cultured potato cells treated with $1 / 10$ volume of NUBS-4190 for a final concentration of $1 \mu \mathrm{g} /$ $\mathrm{mL}$. DMSO $(0.2 \%, \mathrm{v} / \mathrm{v})$ was used as a negative control and methanol extract of mycelia from Phytophthora infestans (MEM) as a positive control. The $\mathrm{O}_{2}{ }^{-}$was measured in a 96-well microtiter plate with L-012 (a reagent to detect $\mathrm{O}_{2}{ }^{-}$) using a chemiluminescence plate reader, Mithras LB 940 (Berthold Technologies, Bad Wildbad, Germany). b $_{2}{ }^{-}$in potato leaves was measured by treating with $10 \mu \mathrm{g} / \mathrm{mL}$ NUBS-4190. Treated leaf areas were infiltrated with L-012 solution $12 \mathrm{~h}$ after treatment and monitored using a CCD camera. Circles indicate areas infiltrated with L-012. c Chemiluminescence intensities of $\mathbf{b}$ were quantified with a photon image processor. Data were analyzed with a Student's $t$ test, $* P<0.05, * * P<0.01$, *** $P<0.001$ (vs DMSO control)

incubated under the same conditions for $48 \mathrm{~h}$. Phytoalexins were extracted from collected liquid from treated holes with an equal amount of ethyl acetate. The extract was separated on TLC plates (TLC aluminum sheet of silica gel 60, Merck, Whitehouse Station, NJ, USA), which were developed with cyclohexane:ethylacetate $(1: 1, \mathrm{v} / \mathrm{v})$ and visualized by spraying with $75 \%$ sulfuric acid containing $0.5 \%(\mathrm{w} / \mathrm{v})$ vanillin followed by heating at $120{ }^{\circ} \mathrm{C}$.
RNA preparation and RT-PCR

Expression of potato genes after the treatment of elicitors was analyzed by RT-PCR (Kato et al. 2008). RT-PCR was conducted using a commercial kit (ReverTra-Plus-; Toyobo Co., Osaka, Japan). The cDNA was synthesized from total RNA ( $1 \mu \mathrm{g})$ with an oligo (dT) primer. After the cDNA synthesis reaction, the PCR was performed with denaturing, annealing, and extension temperatures of $94{ }^{\circ} \mathrm{C}$ for $15 \mathrm{~s}$, $55^{\circ} \mathrm{C}$ for $30 \mathrm{~s}$, and $72{ }^{\circ} \mathrm{C}$ for $30 \mathrm{~s}$, respectively. Genespecific primers for each sequence were as follows: $S t E F-1 \alpha$ forward primer, 5'-ATTGTGCTCATTGGCCACG-3'; StE $F-1 \alpha$ reverse primer, $5^{\prime}$-CCAGTCGAGGTTGGTAGACC3'; StrbohB forward primer, 5'-ATCGAAAACACGAGGG ATTC-3'; StrbohB reverse primer, 5'-GCACCAGACTT ACTCCTATC-3'; StrbohC forward primer, 5'-CGGAAA ATCATCACCCGCAC-3'; StrbohC reverse primer, 5'-C GGCTCCGGCACTAGTTCCG-3'; StPR1 forward primer, 5'-GTGCTAGAGTCAAGTGCAAC-3'; StPRl reverse primer, 5'-GAATCAAAGTCTGGTTGCTC-3'; StNR $1 \alpha$ forward primer, 5'-TCAATTCACGATACTAGAGACG-3', StNR $1 \alpha$ reverse primer, 5'-GCATAAGTCGAGCCAA AGGG-3'; StNR5 forward primer, 5'-TACAACA TTGGCATTGGCTTG-3'; StNR5 reverse primer, 5'-AACA TTTTATACCTAAAGTTAACAA-3'; Sthsr203 $J$ forward primer, $\quad 5^{\prime}$-AAGCTGATTGGTACATGTACTATGC-3'; Sthsr203 $J$ reverse primer, 5'-TAGCTCCGATTTACTTCG CTG-3'; StPAL $1 \alpha$ forward primer, 5'-CTGGTCGGCCTA ATTAAAG-3'; and StPAL $1 \propto$ reverse primer, $5^{\prime}$-GGTTGC AGAACGGATGAC- $3^{\prime}$.

Resistance-inducing activity against pathogen infection

Potato leaves were grown and were sprayed with $10 \mu \mathrm{g} / \mathrm{mL}$ NUBS-4190 in DMSO (1\%, v/v) using a hand sprayer. DMSO $(1 \%, \mathrm{v} / \mathrm{v})$ treatment was used as a control. After $24 \mathrm{~h}$ of treatment, leaves were inoculated with $P$. infestans $\left(2 \times 10^{5}\right.$ zoospores $\left./ \mathrm{mL}\right)$, then kept in dark, humid conditions for $18 \mathrm{~h}$.

\section{Microscopic observations}

Leaves of potato were stained with lactophenol trypan blue (Takemoto et al. 1999) with a minor modification to view cell death and colonization by $P$. infestans. Briefly, infected leaves were cleared in methanol overnight, then the cleared tissue was boiled for $2 \mathrm{~min}$ in lactophenol trypan blue stain $\left(10 \mathrm{~mL}\right.$ of $\mathrm{H}_{2} \mathrm{O}, 10 \mathrm{~mL}$ of lactic acid, $10 \mathrm{~mL}$ of glycerol, $10 \mathrm{~g}$ of phenol, and $10 \mathrm{mg}$ of trypan blue). After the leaves cooled at room temperature for $1 \mathrm{~h}$, the stain was replaced with aqueous chloral hydrate $(1 \mathrm{~g} / \mathrm{mL})$. Stained leaves were monitored using a light microscope (Olympus BX51, Tokyo, Japan). 
Fig. $4 \quad \mathrm{H}_{2} \mathrm{O}_{2}$ accumulation in potato leaves treated with NUBS-4190. a Accumulation of $\mathrm{H}_{2} \mathrm{O}_{2}$ in potato leaves $3,6,12$ and $24 \mathrm{~h}$ after treatment with by NUBS-4190 $(10 \mu \mathrm{g} / \mathrm{mL})$ and incubation with the dye $3,3^{\prime}$ diaminobenzidine (DAB).

Methanol extract of mycelia from Phytophthora infestans (MEM) elicitor $(500 \mu \mathrm{g} / \mathrm{mL})$ was used as positive control, $1 \%(\mathrm{v} / \mathrm{v})$ DMSO as negative control. Reddish brown color indicates $\mathrm{H}_{2} \mathrm{O}_{2}$. Bars $50 \mu \mathrm{m}$. b $\mathrm{H}_{2} \mathrm{O}_{2}$ in leaf tissues was quantified using ImageJ software. Each value represents the mean and standard deviation of 3 replicates. Data were analyzed with Student's $t$-test, $* P<0.05, * * P<0.01$ vs DMSO control
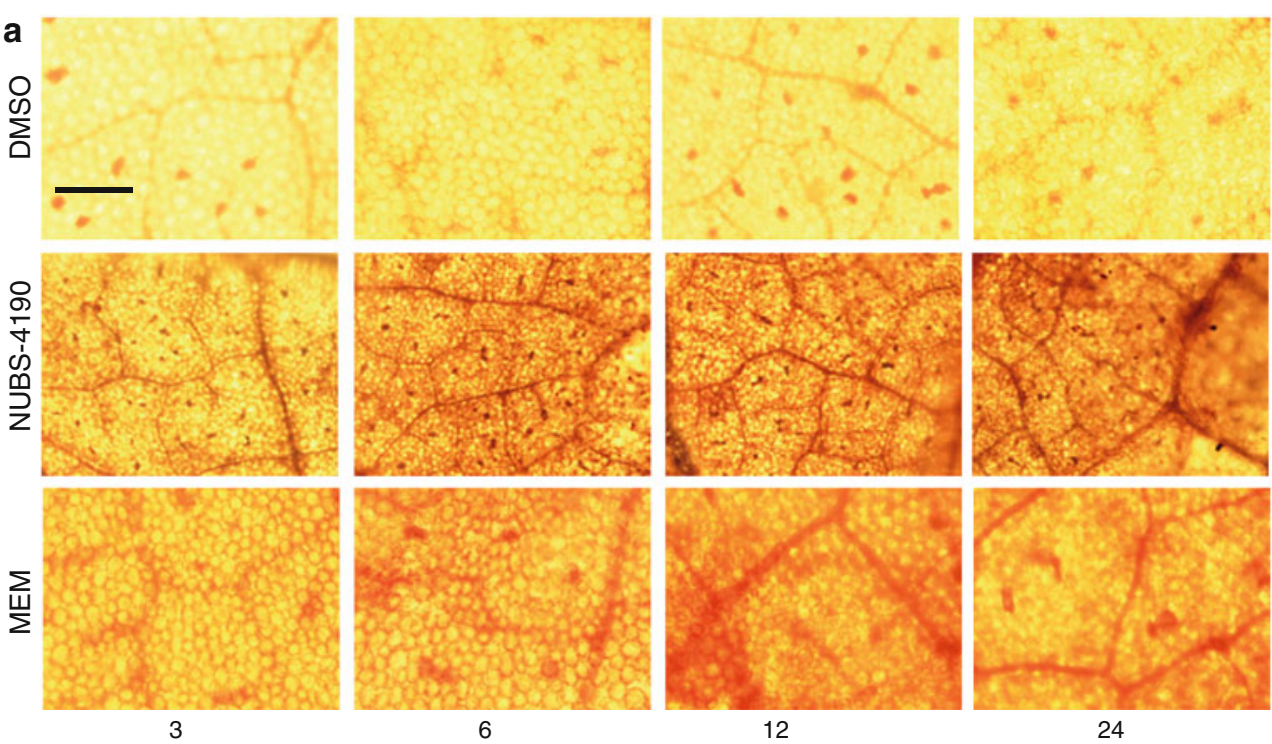

6

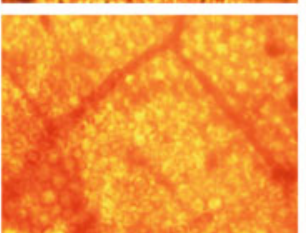

12

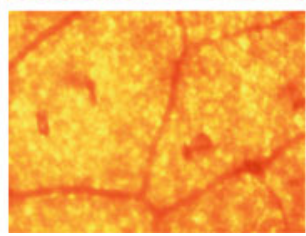

24

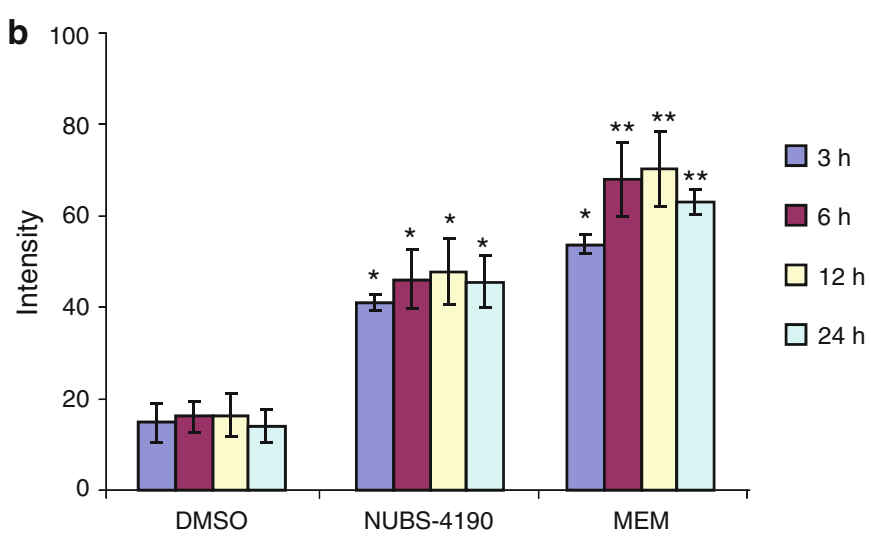

\section{Results}

NO generation

NO generation in a time-course experiment was assayed in suspension cultured cells of potato treated with $10 \mu \mathrm{g} / \mathrm{mL}$ NUBS-4190-treated using DAF-2DA-mediated fluorescence (Fig. 2a). To scavenge NO responsive events in cells, a potent NO scavenger, cPTIO was used. NO generation in the cultured cells treated with NUBS-4190 was eliminated by cPTIO. Higher NO generation was found in the experiment from 1 to $6 \mathrm{~h}$ and peaked $3 \mathrm{~h}$ after treatment (Fig. 2b). NO accumulation in NUBS-4190-treated potato leaves was detected using DAF-2DA-mediated fluorescence with a spectrofluorometric assay. The leaf areas were treated with NUBS-4190 and infiltrated with DAF-2DA solution, and NO production was monitored $1 \mathrm{~h}$ later using fluorescence stereomicroscopy. An increase in fluorescence indicative of NO production was observed when leaves were exposed to $10 \mu \mathrm{g} / \mathrm{mL}$ NUBS-4190 (Fig. 2c, d). The addition of cPTIO suppressed elicitorinduced NO generation indicating that the increase of fluorescence was due to NO production. Increased NO generation was not found in $1 \%(\mathrm{v} / \mathrm{v})$ DMSO-treated potato leaves, rather basal fluorescence was detected by DMSO and did not differ statistically from the cPTIO treatment.

$\mathrm{O}_{2}{ }^{-}$generation

To study the role of NUBS-4190 on $\mathrm{O}_{2}{ }^{-}$induction in potato, we added NUBS-4190 to suspension cultured potato cells and $\mathrm{O}_{2}{ }^{-}$was measured by using the $\mathrm{O}_{2}{ }^{-}$unique luminous reagent L-012. NUBS-4190 induced significantly higher $\mathrm{O}_{2}^{-}$generation in suspension cultured cells (Fig. 3a) and a similar reaction in sites on potato leaves that had been infiltrated with $10 \mu \mathrm{g} / \mathrm{mL}$ of NUBS4190 (Fig. 3b, c). 

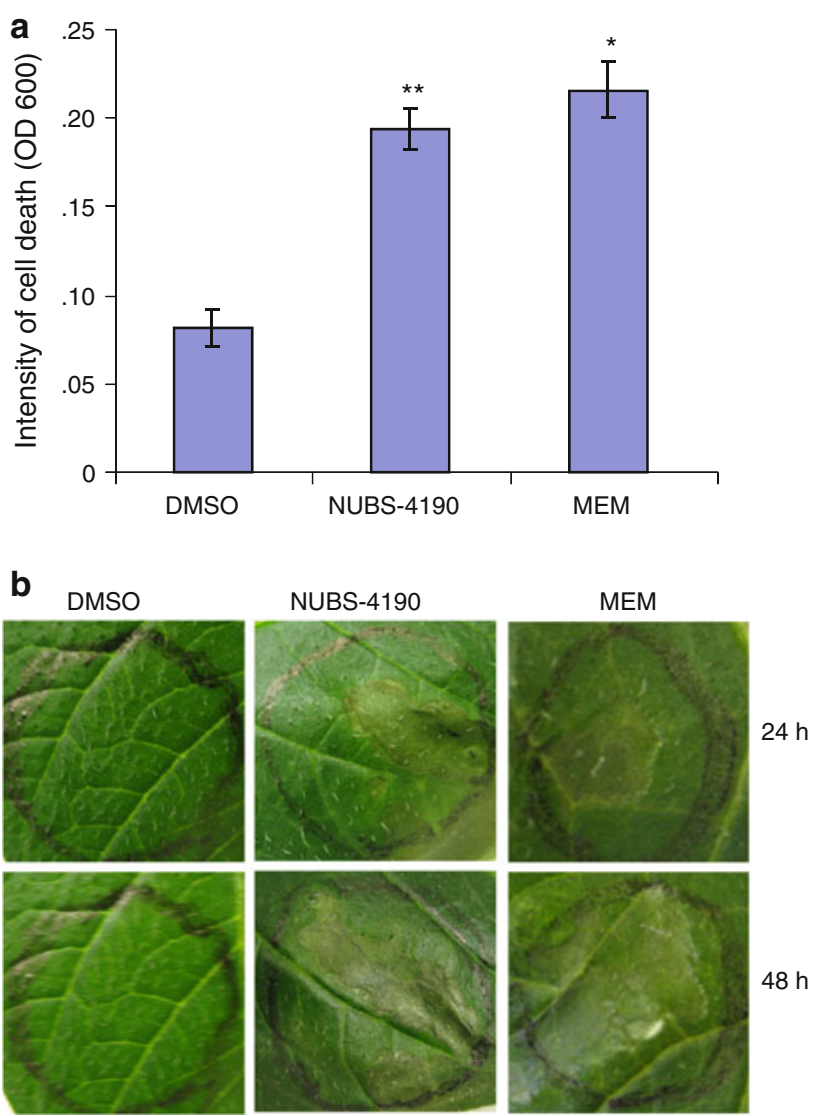

Fig. 5 Induction of cell death by NUBS-4190 in potato. a NUBS-4190 induced hypersensitive cell death in potato suspension cultured cells (Sayaka) after $3 \mathrm{~h}$ treatment. Methanol extract of mycelia from Phytophthora infestans (MEM) elicitor $(500 \mu \mathrm{g} / \mathrm{mL})$ was used as the positive control, $1 \%(\mathrm{v} / \mathrm{v})$ DMSO as the negative control. Dead cells were quantified by adding $0.05 \%$ (w/v) Evans to cell suspensions for $15 \mathrm{~min}$, and $500 \mu \mathrm{L}$ of the cell suspension was washed five times with $1 \mathrm{~mL}$ of distilled water each time to remove excess stain. Dye bound to dead cells was then solubilized in $1 \mathrm{~mL}$ of $50 \%$ methanol that contained $1 \%(\mathrm{w} / \mathrm{v}) \mathrm{SDS}$ for $30 \mathrm{~min}$ at $50{ }^{\circ} \mathrm{C}$, and extracted solution was then quantified by monitoring the absorbance at $600 \mathrm{~nm}$ in spectrophotometer. b Potato leaves were infiltrated with $50 \mu \mathrm{g} / \mathrm{mL}$ NUBS-4190 and incubated for $48 \mathrm{~h}$. Hypersensitive cell death began 8-12 h after elicitor treatment as a wet area on the leaf surface, which increased within a few hours; by $24 \mathrm{~h}$, distinct dead areas were visible. Data were analyzed with Student's $t$ test, $* P<0.05, * * P<0.01$ vs DMSO control

\section{$\mathrm{H}_{2} \mathrm{O}_{2}$ generation}

The effect of NUBS-4190 on $\mathrm{H}_{2} \mathrm{O}_{2}$ accumulation in potato leaves is shown in Fig. 4. $\mathrm{H}_{2} \mathrm{O}_{2}$ generation was detected in NUBS-4190-treated leaves stained with DAB. DAB captures $\mathrm{H}_{2} \mathrm{O}_{2}$ and forms a reddish-brown color at sites of peroxidase activity. $\mathrm{H}_{2} \mathrm{O}_{2}$ production was observed in potato leaves at $3,6,12$ and $24 \mathrm{~h}$ after elicitor treatment. Within $3 \mathrm{~h}$ after treatment, NUBS-4190 induced a high level of $\mathrm{H}_{2} \mathrm{O}_{2}$ and profound reddish brown colors were observed in DAB stained leaves (Fig. 4a, b).

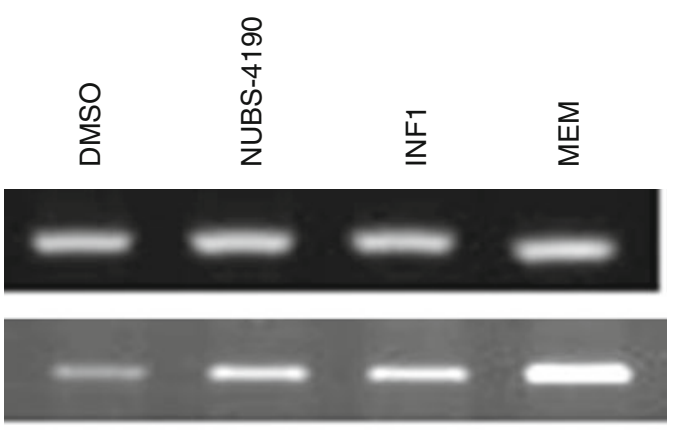

StrbohC

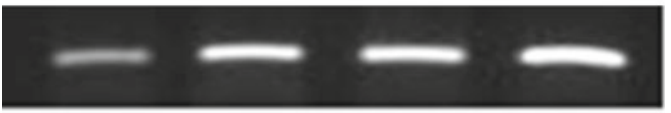

StNR1

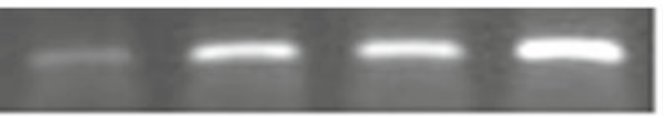

StNR5

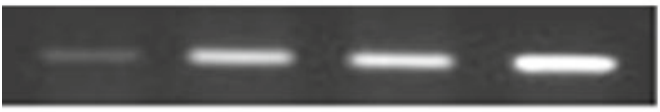

Sthsr203」

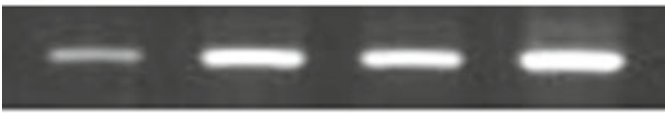

StPR1

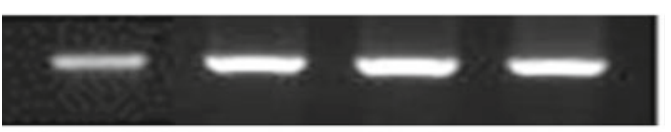

StPAL

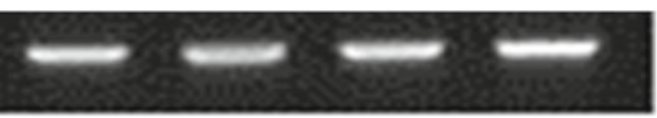

r-RNA

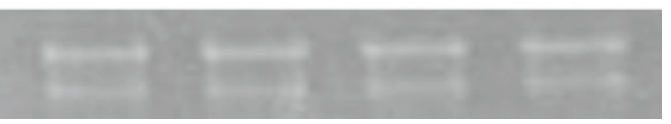

Fig. 6 Gene expression after NUBS-4190 treatment of potato. Total RNAs were isolated from suspension cultured potato cells treated with $1 / 10$ volume of NUBS-4190 or inf1 gene product (INF1) and methanol extract of mycelia from Phytophthora infestans (MEM) as positive control for final concentration of $1,100 \mu \mathrm{g} / \mathrm{mL}$ and $15 \mathrm{nM}$, respectively, for $3 \mathrm{~h}$. DMSO $(1 \%, \mathrm{v} / \mathrm{v})$ was used as a negative control. RNAs were analyzed by RT-PCR using specific primers for StrbohB, StrbohC, StNR1, StNR5, Sthsr203J, StPAL and StPR1. Equal loads of cDNA were monitored by amplification of constitutively expressed $S t E F 1 \alpha$

Induction of cell death

When suspension cultured potato cells were treated with $1 \mu \mathrm{g} / \mathrm{mL}$ NUBS-4190 and stained with the vital stain Evans blue, increased cell death was observed within $3 \mathrm{~h}$ of the treatment (Fig. 5a). Infiltration of potato leaves with $50 \mu \mathrm{g} /$ $\mathrm{mL}$ NUBS-4190 resulted in rapid macroscopic changes; the first symptoms appeared within 18-24 h after the treatment. Leaf tissues in the infiltrated areas gradually died, and dead and dried areas clearly appeared after $48 \mathrm{~h}$ at the infiltrated site (Fig. 5b). 
Fig. 7 NUBS-4190 induced resistance against Phytophthora infestans in potato. a NUBS4190-treated potato leaves and DMSO $(0.2 \%, \mathrm{v} / \mathrm{v})$-treated control leaves were kept in an incubator for $24 \mathrm{~h}$, then inoculated with spores of $P$. infestans. Photographs were taken from 6 days post inoculation. b Appearance of disease symptoms showing differences in severity representative of the five classifications used in c. c Percentages of potato leaves with disease symptom severities in each of the five classes represented in b. Percentage disease severities on treated potato leaves from 1 to 6 days post inoculation with P. infestans. At least 10 inoculated leaves from each plant were counted

\section{a}
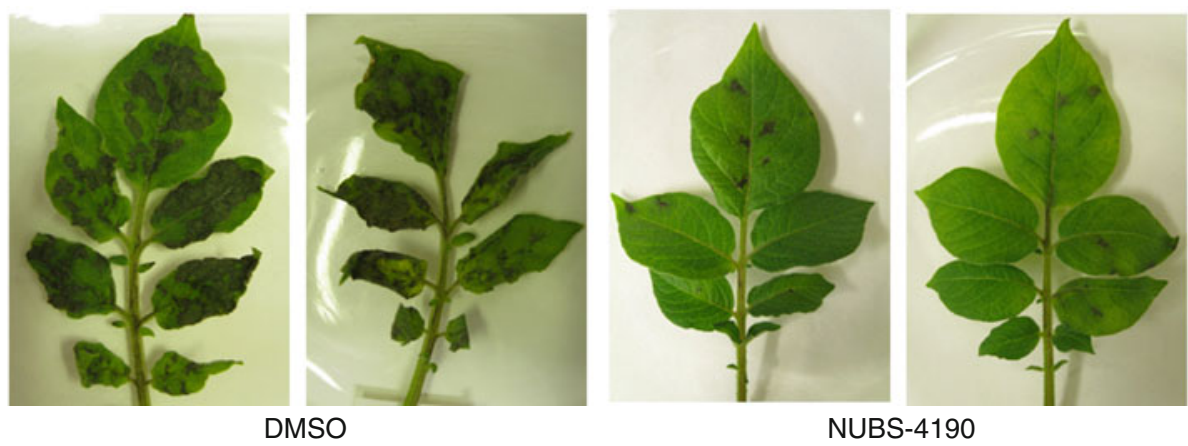

NUBS-4190

b

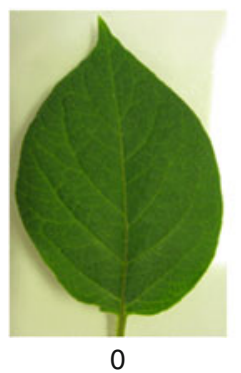

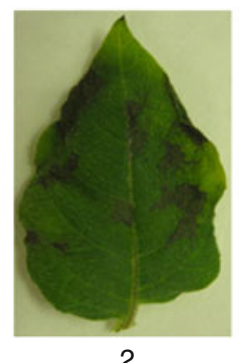

2

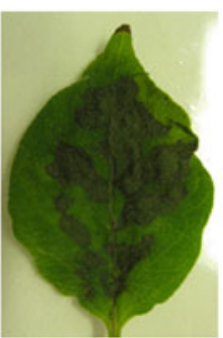

3

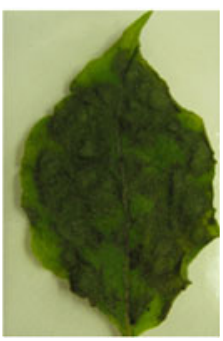

4

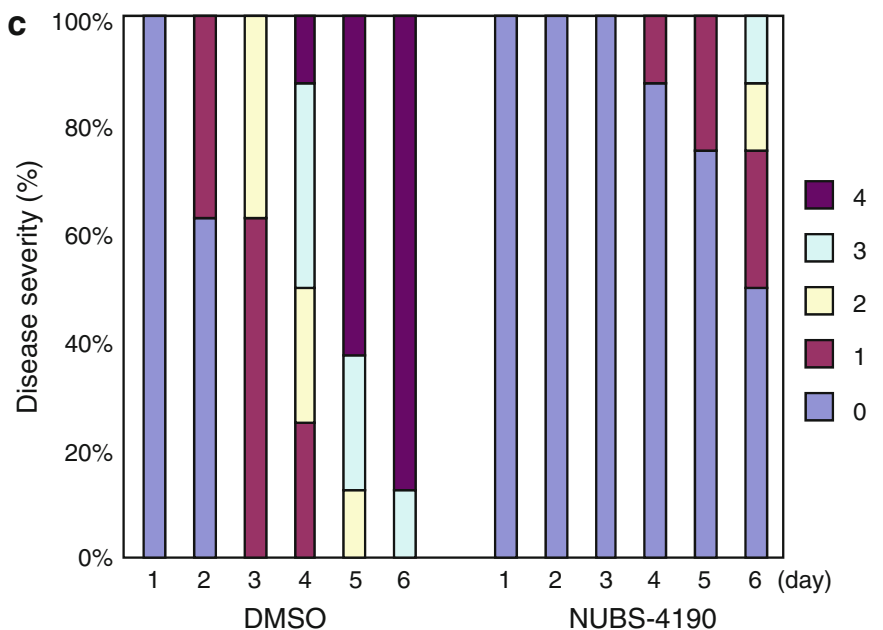

Expression of defense-related genes

To investigate whether defense-related genes are induced by NUBS-4190, we extracted total RNAs from NUBS4190-treated potato suspension cultured cells for analysis by RT-PCR (Fig. 6). INF1 and MEM were used in this experiment as positive controls, i.e., as $\mathrm{NO}$ and $\mathrm{ROS}\left(\mathrm{O}_{2}{ }^{-}\right.$ and $\mathrm{H}_{2} \mathrm{O}_{2}$ ) inducers, respectively, in potato. NUBS-4190 induced expression of StrbohB and StrbohC, suggesting that generation of ROS was induced in potato cells. The expression of the hypersensitive response marker gene Sthsr203J indicated that NUBS-4190 induced HR reaction. Pathogenesis-related 1 (PR1) gene is salicylic-acid responsive and is a useful molecular marker for systemic acquired resistance (SAR) response. High expression of StPRl was found after the NUBS-4190 treatment. Nitrate reductase genes StNR1 and StNR5 were also expressed by NUBS-4190.

Induced disease resistance in potato against $P$. infestans

NUBS-4190 $(10 \mu \mathrm{g} / \mathrm{mL})$ was sprayed on excised leaves, which were inoculated with $P$. infestans 1 day later; excised leaves pretreated with DMSO (2\%) served as a negative control. Within 3 days, DMSO-treated plant leaves developed water-soaked lesions on leaves (Fig. 7a, c), which 


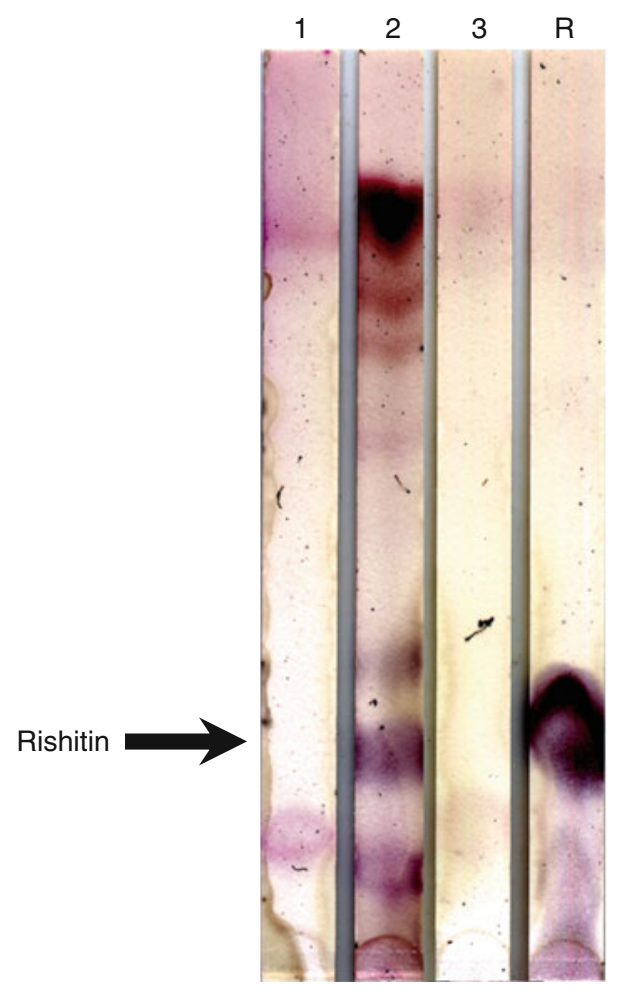

Fig. 8 Phytoalexins did not accumulate after $40 \mu \mathrm{g} / \mathrm{mL}$ NUBS-4190 treatment of potato tubers. Phytoalexins, extracted $48 \mathrm{~h}$ after treatment, and $25 \mu \mathrm{g}$ of purified rishitin were separated and developed on a TLC plate. 1, DMSO; $2,1 \mathrm{mg} / \mathrm{mL}$ methanol extract of mycelia from Phytophthora infestans (MEM) elicitor; 3, $40 \mu \mathrm{g} / \mathrm{mL}$ NUBS-4190 and $\mathrm{R}$, rishitin

expanded to nearly cover the leaves within 7-8 days. In contrast, few spots developed on leaves treated with NUBS4190. Resistance against $P$. infestans was not recorded in $0.2 \%$ DMSO-treated potato leaves.

Phytoalexins accumulation

Potato tubers were treated with NUBS-4190 or MEM elicitor as a positive control or $0.4 \%$ DMSO as a negative control. No phytoalexins were found in the TLC separation of extracts from NUBS-4190-treated potato tubers (Fig. 8).

\section{Discussion}

Elicitor-induced secondary metabolite production has been characterized as mediated by endogenous signaling. Among signal molecules, NO has been reported to play an important role (Xu 2007; Zhao et al. 2005). In the present situation concerning the NO-eliciting synthetic bis-aryl methanone compound, NUBS-4190, NO generation was triggered in potato (Fig. 2) similar to our previous study, in which NUBS-4190 induced NO-mediated resistance against $P$. infestans in $N$. benthamiana (Monjil et al. 2013). NO induction by NUBS-4190 in potato is sharp and reproducible, and NUBS-4190 could be a good synthetic compound for NO induction in potato. Although there has been criticism about the specificity of DAFfluorescence for detecting NO (Rümer et al. 2012), we confirmed NO generation by showing high expression of nitrate reductase genes StNR1 and StNR5 in NUBS-4190treated potato (Fig. 6).

The oxidative burst, one of the most rapid defense reactions to pathogen attack, which constitutes the production of ROS, primarily $\mathrm{O}_{2}{ }^{-}$and $\mathrm{H}_{2} \mathrm{O}_{2}$, at the site of attempted invasion (Apostol et al. 1989). In the present study, ROS was induced in NUBS-4190-treated leaves and suspension cultured cells of potato (Figs. 3, 4). In our previous study (Monjil et al. 2013), NUBS-4190 induced NO but not ROS in $N$. benthamiana. These results indicate that potato and $N$. benthamiana and/or the signal pathways responsible for ROS production may differ in their sensitivity to NUBS4190. When NUBS-4190 induced NO in N. benthamiana, signals for ROS production might not be transduced and/or NO suppressed the production of ROS. Reducing the endogenous NO level using cPTIO or plant mutants impaired in inducible $\mathrm{NO}$ production enhanced $\mathrm{H}_{2} \mathrm{O}_{2}$ accumulation (Asai et al. 2008; Tada et al. 2004), suggesting that part of the $\mathrm{O}_{2}{ }^{-}$produced by NADPH oxidase is scavenged by NO. Yun et al. (2011) found that NO abolished AtrbohD activity through $S$-nitrosylation.

An HR-like cell death was observed in NUBS-4190treated potato leaves and suspension cultured cells (Fig. 5). When $\mathrm{O}_{2}{ }^{-}$and $\mathrm{H}_{2} \mathrm{O}_{2}$ levels increase in plants in response to pathogen attack, a HR results in the death of host cells (Apel and Hirt 2004). NO also induces plant defense responses including cell death (Wendehenne et al. 2004). It is reported that NO and ROS together, but not individually, are required to induce cell death (Delledonne et al. 1998). A balanced production of $\mathrm{NO}$ and $\mathrm{O}_{2}{ }^{-}$results in production of $\mathrm{ONOO}^{-}$and is important for inducing HR-like cell death (Saito et al. 2006). On the other hand, NO has been reported as not necessary to induce HR-like cell death (Wang et al. 2010). Da Silva et al. (2011) reported that dihydrosphingosine-induced NO production in tobacco BY-2 cells is not necessary for the induction of HR-like cell death. These reports suggest that NUBS-4190 induced both ROS and NO production in potato, which is responsible for leading to cell death.

In potato, a group of defense response-related genes, namely StrbohB, StrbohC, StPRI, StNRI and StNR5 were expressed after NUBS-4190 treatment (Fig. 6), indicating that NUBS-4190 plays an important role in defense-related gene expression. To examine whether defense activities such as ROS, NO and HR-like cell death are effective against the pathogen, NUBS-4190-treated potato leaves 
were inoculated with $P$. infestans, and a higher level of resistance in potato was stimulated at the stage susceptible to $P$. infestans (Fig. 7). Moreover, StPRI gene expression provided the systemic nature of this resistance.

After elicitor treatment, ROS generation is not essential to induce phytoalexin accumulation in plants. We showed that NUBS-4190 induced ROS and NO in potato but the level was not sufficient to induce phytoalexin accumulation. Doke (1983) reported that $\mathrm{O}_{2}{ }^{-}$generation is closely connected with phytoalexin production by hyphal wall components from $P$. infestans. In contrast, it had been reported that $\mathrm{N}, \mathrm{N}$-dimethylsphingosine induces phytoalexin production and hypersensitive cell death of Solanaceae plants without generation of ROS (Uruma et al. 2009). Devlin and Gustine (1992) reported that induction of phytoalexins was not dependent on ROS in white clover suspension cultures treated with avirulent Pseudomonas corrugata or with mercuric chloride. Treatment with DPI, a flavoprotein inhibitor of NADPH oxidase, blocks ROS generation but does not interfere with the induction of phytoalexins (Hahlbrock et al. 1995). Thus, whether ROS is involved in phytoalexins accumulation may depend on the plant species.

NUBS-4190 is a synthetic compound that elicits the HR in potato leaves and induces the production of multiple signaling molecules such as ROS and NO and the expression of the PR1 gene to enhance systemic resistance. These results indicate that NUBS-4190 has potential as an activating agent of potato plant defense.

Open Access This article is distributed under the terms of the Creative Commons Attribution License which permits any use, distribution, and reproduction in any medium, provided the original author(s) and the source are credited.

\section{References}

Apel K, Hirt H (2004) Reactive oxygen species: metabolism, oxidative stress, and signal transduction. Annu Rev Plant Biol 55:373-399

Apostol I, Heinstein PF, Low PS (1989) Rapid stimulation of an oxidative burst during elicitation of cultured plant cells. Role in defense and signal transduction. Plant Physiol 90:109-116

Arasimowicz-Jelonek M, Floryszak-Wieczorek J, Kubiś J (2009) Interaction between polyamine and nitric oxide signaling in adaptive responses to drought in cucumber. J Plant Growth Regul 28:177-186

Asai S, Yoshioka H (2009) Nitric oxide as a partner of reactive oxygen species participates in disease resistance to necrotrophic pathogen Botrytis cinerea in Nicotiana benthamiana. Mol Plant Microbe Interact 22:619-629

Asai S, Ohta K, Yoshioka H (2008) MAPK signaling regulates nitric oxide and NADPH oxidase-dependent oxidative bursts in Nicotiana benthamiana. Plant Cell 20:1390-1406

Besson-Bard A, Pugin A, Wendehenne D (2008) New insights into nitric oxide signaling in plants. Annu Rev Plant Biol 59:21-39

Billard V, Bruneteau M, Bonnet Ph, Ricci P, Pernollet JC, Huet JC, Vergne A, Richard G, Michel G (1988) Chromatographic purification and characterization of elicitors of necrosis on tobacco produced by incompatible Phytophthora species. J Chromatogr 440:87-94

Boccara M, Mills CE, Zeier J, Anzi C, Lamb C, Poole RK, Delledonne M (2005) Flavohaemoglobin HmpX from Erwinia chrysanthemi confers nitrosative stress tolerance and affects the plant hypersensitive reaction by intercepting nitric oxide produced by the host. Plant J 43:226-237

Cecconi D, Orzetti S, Vandelle E, Rinalducci S, Zolla L, Delledonne M (2009) Protein nitration during defense response in Arabidopsis thaliana. Electrophoresis 30:2460-2468

Cheong JJ, Birberg W, Fügedi P, Pilotti A, Garegg PJ, Hong N, Ogawa T, Hahn MG (1991) Structure-activity relationships of oligo- $\beta$-glucoside elicitors of phytoalexin accumulation in soybean. Plant Cell 3:127-136

Clarke A, Desikan R, Hurst RD, Hancock JT, Neill SJ (2000) NO way back: nitric oxide and programmed cell death in Arabidopsis thaliana suspension cultures. Plant J 24:667-677

Da Silva D, Lachaud C, Cotelle V, Brière C, Grat S, Mazars C, Thuleau $P$ (2011) Nitric oxide production is not required for dihydrosphingosine-induced cell death in tobacco BY-2 cells. Plant Signal Behav 6:736-739

Dangl JL, Dietrich RA, Richberg MH (1996) Death don't have no mercy: cell death programs in plant-microbe interactions. Plant Cell 8:1793-1807

Delledonne M (2005) NO news is good news for plants. Curr Opin Plant Biol 8:390-396

Delledonne M, Xia YJ, Dixon RA, Lamb C (1998) Nitric oxide functions as a signal in plant disease resistance. Nature 394:585-588

Delledonne M, Zeier J, Marocco A, Lamb C (2001) Signal interactions between nitric oxide and reactive oxygen intermediates in the plant hypersensitive disease resistance response. Proc Natl Acad Sci USA 98:13454-13459

Devlin WS, Gustine DL (1992) Involvement of the oxidative burst in phytoalexin accumulation and the hypersensitive reaction. Plant Physiol 100:1189-1195

Doke N (1975) Prevention of the hypersensitive reaction of potato cells to infection with an incompatible race of Phytophthora infestans by constituents of the zoospores. Physiol Plant Pathol 7:1-7

Doke N (1983) Generation of superoxide anion by potato tuber protoplasts during hypersensitive response to hyphal wall components of Phytophthora infestans and specific inhibition of the reaction by suppressors of hypersensitivity. Physiol Plant Pathol 23:359-367

Durner J, Wendehenne D, Klessig DF (1998) Defense gene induction in tobacco by nitric oxide, cyclic GMP, and cyclic ADP-ribose. Proc Natl Acad Sci USA 95:10328-10333

Felix G, Regenass M, Boller T (1993) Specific perception of subnanomolar concentrations of chitin fragments by tomato cells: induction of extracellular alkalinization, changes in protein phosphorylation, and establishment of a refractory state. Plant $\mathbf{J}$ 4:307-316

Felix G, Duran JD, Volko S, Boller T (1999) Plants have a sensitive perception system for the most conserved domain of bacterial flagellin. Plant J 18:265-276

Goellner K, Conrath U (2008) Priming: it's all the world to induced disease resistance. Eur J Plant Pathol 121:233-242

Hahlbrock K, Scheel D, Logeman E, Nürnberger T, Parniske M, Reinhold S, Sacks WR, Schmelzer E (1995) Oligopeptide elicitor mediated defense gene activation in cultured parsley cells. Proc Natl Acad Sci USA 92:4150-4157

Heath MC (2000) Hypersensitive response-related death. Plant Mol Biol 44:321-334

Huang X, von Rad U, Durner J (2002) Nitric oxide induces transcriptional activation of the nitric oxide-tolerant alternative oxidase in Arabidopsis suspension cells. Planta 215:914-923 
Jakab G, Cottier V, Toquin V, Rigoli G, Zimmerli L, Métraux J-P, Mauch-Mani B (2001) $\beta$-Aminobutyric acid-induced resistance in plants. Eur J Plant Pathol 107:29-37

Kamoun S, van West P, de Jong AJ, de Groot KE, Vleeshouwers VGAA, Govers F (1997) A gene encoding a protein elicitor of Phytophthora infestans is down-regulated during infection of potato. Mol Plant Microbe Interact 10:13-20

Kato H, Asai S, Yamamoto-Katou A, Yoshioka H, Doke N, Kawakita $\mathrm{K}$ (2008) Involvement of NbNOAl in NO production and defense responses in INF1-treated Nicotiana benthamiana. J Gen Plant Pathol 74:15-23

Kobayashi M, Ohura I, Kawakita K, Yokota N, Fujiwara M, Shimamoto K, Doke N, Yoshioka H (2007) Calcium-dependent protein kinases regulate the production of reactive oxygen species by potato NADPH oxidase. Plant Cell 19:1065-1080

Lam E, Kato N, Lawton M (2001) Programmed cell death, mitochondria and the plant hypersensitive response. Nature 411:848-853

Locato V, Gadaleta C, De Gara L, de Pinto MC (2008) Production of reactive species and modulation of antioxidant network in response to heat shock: a critical balance for cell fate. Plant Cell Environ 31:1606-1619

Monjil MS, Shibata Y, Takemoto D, Kawakita K (2013) Bis-aryl methanone compound is a candidate of nitric oxide producing elicitor and induces resistance in Nicotiana benthamiana against Phytophthora infestans. Nitric Oxide 29:34-45

Mühlenbock P, Plaszczyca M, Plaszczyca M, Mellerowicz E, Karpinski S (2007) Lysigenous aerenchyma formation in Arabidopsis is controlled by LESION SIMULATING DISEASE1. Plant Cell 19:3819-3830

Mur LAJ, Kenton P, Lloyd AJ, Ougham H, Prats E (2008) The hypersensitive response; the centenary is upon us but how much do we know? J Exp Bot 59:501-520

Murgia I, de Pinto MC, Delledonne M, Soave C, De Gara L (2004) Comparative effects of various nitric oxide donors on ferritin regulation, programmed cell death, and cell redox state in plant cells. J Plant Physiol 161:777-783

Noritake T, Kawakita K, Doke N (1996) Nitric oxide induces phytoalexin accumulation in potato tuber tissues. Plant Cell Physiol 37:113-116

Nürnberger T, Nennstiel D, Jabs T, Sacks WR, Hahlbrock K, Scheel D (1994) High affinity binding of a fungal oligopeptide elicitor to parsley plasma membranes triggers multiple defense responses. Cell 78:449-460

Orozco-Cárdenas ML, Ryan CA (2002) Nitric oxide negatively modulates wound signaling in tomato plants. Plant Physiol 130:487-493

Parani M, Rudrabhatla S, Myers R, Weirich H, Smith B, Leaman DW, Goldman SL (2004) Microarray analysis of nitric oxide responsive transcripts in Arabidopsis. Plant Biotech J 2:359-366

Perazzolli M, Dagostin S, Ferrari A, Elad Y, Pertot I (2008) Induction of systemic resistance against Plasmopara viticola in grapevine by Trichoderma harzianum T39 and benzothiadiazole. Biol Control 47:228-234

Perchepied L, Balagué C, Riou C, Claudel-Renard C, Rivière N, Grezes-Besset B, Roby D (2010) Nitric oxide participates in the complex interplay of defense-related signaling pathways controlling disease resistance to Sclerotinia sclerotiorum in Arabidopsis thaliana. Mol Plant Microbe Interact 23:846-860

Rasul S, Dubreuil-Maurizi C, Lamotte O, Koen E, Poinssot B, Alcaraz G, Wendehenne D, Jeandroz S (2012) Nitric oxide production mediates oligogalacturonide-triggered immunity and resistance to Botrytis cinerea in Arabidopsis thaliana. Plant, Cell Environ 35:1483-1499
Rümer S, Krischke M, Fekete A, Mueller MJ, Kaiser WM (2012) DAF-fluorescence without NO: elicitor treated tobacco cells produce fluorescing DAF-derivatives not related to DAF-2 triazol. Nitric Oxide 27:123-135

Saito S, Yamamoto-Katou A, Yoshioka H, Doke N, Kawakita K (2006) Peroxynitrite generation and tyrosine nitration in defense responses in tobacco BY-2 cells. Plant Cell Physiol 47:689-697

Tada Y, Mori T, Shinogi T, Yao N, Takahashi S, Betsuyaku S, Sakamoto M, Park P, Nakayashiki H, Tosa Y, Mayama S (2004) Nitric oxide and reactive oxygen species do not elicit hypersensitive cell death but induce apoptosis in the adjacent cells during the defense response of oat. Mol Plant Microbe Interact 17:245-253

Takemoto D, Maeda H, Yoshioka H, Doke N, Kawakita K (1999) Effect of cytochalasin D on defense responses of potato tuber discs treated with hyphal wall components of Phytophthora infestans. Plant Sci 141:219-226

Thordal-Christensen H, Zhang Z, Wei Y, Collinge DB (1997) Subcellular localization of $\mathrm{H}_{2} \mathrm{O}_{2}$ in plants. $\mathrm{H}_{2} \mathrm{O}_{2}$ accumulation in papillae and hypersensitive response during the barley-powdery mildew interaction. Plant J 11:1187-1194

Torres MA (2010) ROS in biotic interactions. Physiol Plant 138:414-429

Uruma S, Shibata Y, Takemoto D, Kawakita K (2009) $\mathrm{N}, \mathrm{N}$ Dimethylsphingosine, an inhibitor of sphingosine kinase, induces phytoalexin production and hypersensitive cell death of Solanaceae plants without generation of reactive oxygen species. J Gen Plant Pathol 75:257-266

Vacca RA, de Pinto MC, Valenti D, Passarella S, Marra E, De Gara L (2004) Production of reactive oxygen species, alteration of cytosolic ascorbate peroxidase, and impairment of mitochondrial metabolism are early events in heat shock-induced programmed cell death in tobacco bright-yellow 2 cells. Plant Physiol 134:1100-1112

Vallad GE, Goodman RM (2004) Systemic acquired resistance and induced systemic resistance in conventional agriculture. Crop Sci 44:1920-1934

Wang Y, Chen C, Loake GJ, Chu C (2010) Nitric oxide: promoter or suppressor of programmed cell death? Protein Cell 1:133-142

Wendehenne D, Durner J, Klessig DF (2004) Nitric oxide: a new player in plant signalling and defence responses. Curr Opin Plant Biol 7:449-455

Wilson ID, Neill SJ, Hancock JT (2008) Nitric oxide synthesis and signalling in plants. Plant Cell Environ 31:622-631

Xu MJ (2007) Nitric oxide: a potential key point of the signaling network leading to plant secondary metabolite biosynthesis. Prog Nat Sci 17:1397-1404

Yamamoto A, Katou S, Yoshioka H, Doke N, Kawakita K (2004) Involvement of nitric oxide generation in hypersensitive cell death induced by elicitin in tobacco cell suspension culture. J Gen Plant Pathol 70:85-92

Yeom SI, Baek HK, Oh SK, Kang WH, Lee SJ, Lee JM, Seo E, Rose JKC, Kim BD, Choi D (2011) Use of a secretion trap screen in pepper following Phytophthora capsici infection reveals novel functions of secreted plant proteins in modulating cell death. Mol Plant Microbe Interact 24:671-684

Yun BW, Feechan A, Yin MH, Saidi NBB, Le Bihan T, Yu M, Moore JW, Kang JG, Kwon E, Spoel SH, Pallas JA, Loake GJ (2011) Snitrosylation of NADPH oxidase regulates cell death in plant immunity. Nature 478:264-268

Zaninotto F, La Camera S, Polverari A, Delledonne M (2006) Cross talk between reactive nitrogen and oxygen species during the hypersensitive disease resistance response. Plant Physiol 141:379-383 
Zhao J, Davis LC, Verpoorte R (2005) Elicitor signal transduction leading to production of plant secondary metabolites. Biotech Adv 23:283-333

Zipfel C, Robatzek S, Navarro L, Oakeley EJ, Jones JDG, Felix G, Boller T (2004) Bacterial disease resistance in Arabidopsis through flagellin perception. Nature 428:764-767
Zurbriggen MD, Carrillo N, Tognetti VB, Melzer M, Peisker M, Hause B, Hajirezaei MR (2009) Chloroplast-generated reactive oxygen species play a major role in localized cell death during the non-host interaction between tobacco and Xanthomonas campestris pv. vesicatoria. Plant J 60:962-973 